\title{
YIELD AND QUALITY OF TOMATO (Lycopersicon esculentum Mill.) FRUIT HARVESTED FROM PLANTS GROWN IN MULCHED SOIL
}

\author{
Joanna Majkowska-Gadomska, Brygida Wierzbicka, Katarzyna Arcichowska
}

\author{
Department of Horticulture, University of Warmia and Mazury in Olsztyn, ul. Prawocheńskiego 21, 10-957 Olsztyn, Poland \\ e-mail: majkowska-gadomska@uwm.edu.pl
}

Received: 30.04 .2012

\begin{abstract}
A study investigating the yield of field-grown tomatoes was conducted in 2007-2009 in the Garden of the Research and Experimental Station of the University of Warmia and Mazury in Olsztyn. The experimental materials comprised two tomato cultivars, 'Bawole Serce' and 'Złoty Ożarowski'. Tomato plants were grown in bare soil and in soil mulched with black non-woven PP 50 fabric. Cultivar selection had a significant effect only on average early yield of 'Bawole Serce'. The highest average early yield for three years of the study was recorded for 'Bawole Serce' grown in mulched soil, while the lowest one for 'Złoty Ożarowski" grown in mulched plots. Tomato marketable yield was significantly higher in both treatments where 'Bawole Serce' plants were grown. Fruits harvested from tomato plants 'Złoty Ożarowski' had a higher dry matter content. Soil mulching significantly increased the dry matter content of 'Złoty Ożarowski' tomato fruit. The experimental factors had no influence on the concentrations of L-ascorbic acid, total sugars, and organic acids. Nitrate levels in tomato fruit were within permissible limits, and they were significantly affected by the cultivation method and the method $\mathrm{x}$ cultivar interaction. Nitrate accumulation was reduced in tomato plants 'Złoty Ożarowski' grown in mulched soil.
\end{abstract}

Key words: Lycopersicon esculentum, cultivar, yield, mulching, dry matter, organic compounds, nitrates.

\section{INTRODUCTION}

Tomatoes (Lycopersicon esculentum Mill.) are grown and consumed throughout the world (B a b i k, 1997). The increasing economic significance of tomato fruits is a consequence of their high biological value, specific taste and flavor as well as a wide range of uses and applications (Kołota and Winiarska, 2005). In Poland, the total area of field-grown tomatoes is 12,244 ha, with an estimated yield of $21.0 \mathrm{t}$ per ha (Rocznik Statystyczny Rolnictwa, 2009). Soil mulching is particularly recommended for thermophilous vegetables. A protective cover is placed over the soil prior to planting out the seedlings. A variety of materials are used as mulches, including organic materials such as straw, hay, and compost, as well as synthetic materials such as wax paper and aluminum foil (W a g g o ner et al. 1960). Commonly applied mulches are also black PE sheets and black non-woven PP fabrics (S i w e k et al. 2007). Biodegradable mulch films considered "environmentally friendly" can also be used, however the process of their decomposition poses the risk of soil contamination with heavy metals (S i w e k et al. 2010). The benefits of mulching include an improvement in soil texture and plant nutrient utilization (Kosterna et al. 2010; A d a m c zew ska-Sowińska and Kołota, 2010). Dark-colored mulches suppress weed growth and contribute to eliminating the use of herbicides in vegetable production (B u c z k o w s k a , 1999). In the cultivation of dwarf tomatoes, mulch can help keep fruit up off the ground, which ensures cleaner fruit and reduces the development of pathogenic infections ( $\mathrm{G}$ a l a m b o s i and S zeben i- Gal a mbosi, 1992).

The objective of this study was to determine the effect of soil mulching on fruit yield and the nutritional value of field-grown tomatoes.

\section{MATERIALS AND METHODS}

A two-factorial field experiment was conducted in 2007-2009 in the Garden of the Research and Experimental Station of the University of Warmia and Mazury in Olsztyn. The first experimental factor was tomato cultivar - 'Bawole Serce' and 'Złoty Ożarowski'. The second experimental factor was cultivation method - tomato plants were grown in bare soil and in soil mulched with black non-woven PP 50 fabric. 
Seedlings were grown in a greenhouse, in line with the generally observed standards for tomato cultivation. Seeds were dressed with Seed Dressing $T$ and were sown in boxes for seedlings on 30 March. Each year, on 12 April, seedlings were planted out in $10 \mathrm{~cm}$ diameter pots filled with peat substrate with the following chemical composition: $\mathrm{N}-\mathrm{NO}_{3}-100 ; \mathrm{P}-80 ; \mathrm{K}-215$; $\mathrm{Ca}-1240 ; \mathrm{Mg}-121 \mathrm{mg} \times \mathrm{dm}^{-3} ; \mathrm{pH}$ in $\mathrm{H}_{2} \mathrm{O}-5.9$; salt concentration $-1.5 \mathrm{~g} \times \mathrm{dm}^{-3}$.

During seedling production, $2 \%$ Ekosol U was applied twice to the leaves. Seven days before the planned transplant date, the seedlings were hardened off by reducing watering and providing good air circulation. One day prior to the planting out of seedlings, non-woven fabric was spread over the soil surface and openings were made in the fabric. Seedlings were planted in the openings towards the end of May, at a spacing of $100 \times 50 \mathrm{~cm}$. Ten seedlings of each cultivar were planted in each plot with a surface area of $15 \mathrm{~m}^{2}$. The plants were pruned for one stem, and were supported with stakes. In the first week of August, the plants were topped, leaving two leaves above the fourth cluster. Soil moisture deficits were compensated for by sprinkling irrigation.

The experiment was carried out in a split-plot design, in three replications. Tomatoes were grown in hortic anthrosol containing $2.8 \%$ humus in the ploughing layer, with $\mathrm{pH}$ in $\mathrm{H}_{2} \mathrm{O}-7.1$, salt concentration $-0.36 \mathrm{~g} \times \mathrm{dm}^{-3}$ and the following nutrient content: $\mathrm{N}-\mathrm{NO}_{3}-34 ; \mathrm{P}-90 ; \mathrm{K}-194 ; \mathrm{Ca}-2880 ; \mathrm{Mg}-146$; $\mathrm{Cl}-16 \mathrm{~g} \times \mathrm{dm}^{-3}$. Nitrogen was applied up to a level of $120 \mathrm{mg} \times \mathrm{dm}^{-3}$ so as to meet the species' requirements (S t a r c k, 1997). Weather data were provided by the Hydrological and Meteorological Station in Olsztyn.

The harvest began on 28 July and ended on 7 September in 2007 and 2008, and on 21 September in 2009. Early, marketable and total yield were determined for both cultivars (Commission Regulation [EU] No. 46/2003). Early yield comprised fruits harvested during the first three harvest series, marketable yield consisted of healthy fruits more than $3.5 \mathrm{~cm}$ in diameter, and total yield comprised all harvested fruits. Fifteen ripe tomato fruits were picked (20.08) per treatment to determine dry matter content - by drying the collected plant material at $105^{\circ} \mathrm{C}$ to constant weight (PN-90/A-75101/03), L-ascorbic acid - by the Tillmans method modified by Pijanowski (PN-90A-75101/11), sugars - by the Luff-Schoorl method (PN-90/A-75101/07), organic acids - expressed as malic acid equivalents, as described by Pieterburgski, and nitrates - by the colorimetric method with the use of salicylic acid (Kra u ze and D o mska, 1991). The total sugar to organic acid ratio and the ascorbate index (an indicator of the levels of ascorbic acid and nitrates, $\mathrm{I}_{\mathrm{AN}}$ ) were also calculated.
Tomato yield and nutrient content values were subjected to an analysis of variance. The significance of differences between means was determined by Tukey's test at $\alpha=0.05$.

\section{RESULTS AND DISCUSSION}

Plastic mulch is used in large-scale production of thermophilous vegetable crops (Candido et al. 2006; G i a n n o c caro et al. 2008; Vetrano et al. 2009). In the region of Cracow, black PE sheet and black non-woven fabric used as mulches increased soil temperature during the day by $3-4^{\circ} \mathrm{C}$ and $1-2^{\circ} \mathrm{C}$ on average, respectively (S i w e k and Li bi k, 2005). Soil mulching is particularly recommended for thermophilous vegetables in areas characterized by less favorable weather conditions ( $\mathrm{Majkowsk-Ga-}$ d o m s k a , 2010). The geographical regions of Poland differ with respect to prevailing climatic conditions ( $\mathrm{G} \mathrm{rabow} \mathrm{s} \mathrm{ki}$ et al. 2007). The local climate in Warmia and Mazury is quite severe and much colder, compared with other regions (Koźmiński and $\mathrm{Mi}$ chalska, 2001). The annual precipitation amount, although greater than in adjacent areas, is insufficient to meet crop water demand. In addition, short wet and dry spells alternate in the region of Warmia and Mazury (G rabow ska et al. 2004).

Over the experimental period, weather conditions varied insignificantly during the tomato growing seasons (Figs 1, 2). In the warmest year 2008, the average temperature in the tomato growing season reached $16.2^{\circ} \mathrm{C}$, while in the coldest year 2009 the mean temperature was $15.8^{\circ} \mathrm{C}$. The highest rainfall total was in $2007(481.6 \mathrm{~mm})$, and the lowest precipitation amount was recorded in 2008 (242.4 mm).

The key to high tomato yields is the selection of appropriate cultivars, recommended for open ground (Akintoye et al. 2005; Adamczewska-Sow in s k a and Kołota, 2007). In the present study, two tomato cultivars differed significantly only with respect to early fruit yield (Table 1). An analysis of the means of three years of the study revealed that $\mathrm{cv}$. 'Bawole Serce' produced significantly higher yield during the first three harvests $\left(14.9 \mathrm{t} \times \mathrm{ha}^{-1}\right)$ than cv. 'Zloty Ożarowski'. The obtained yield values are comparable with those reported by Akintoye et al. (2005) as well as Adamczewska-Sowińska and Koło ta (2007) for tomatoes grown in open field with organic mulches. Substantially higher fruit yield of field-grown tomatoes was obtained by Ko to t a and W i n i a r s k a , (2005), but the cited study was carried out in a much warmer region of Poland.

In 2007, soil mulching contributed to a significant increase in early yield of 'Bawole Serce'. In 2009, a greater yield-increasing effect was noted in the 
control treatment. The significant decrease in early yield of tomato fruit in the mulched plots, observed in 2009 , could be due to limited access to water in July, which was very dry. The average early yield for three years of the study ranged from $10.5 \mathrm{t} \times \mathrm{ha}^{-1}$ in the control treatment to $14.5 \mathrm{t} \times \mathrm{ha}^{-1}$ in mulched plots, but the noted differences were statistically non-significant. In 2008, marketable yield of tomato fruit was by $12.4 \mathrm{t} \times$ $\mathrm{ha}^{-1}$ higher in non-mulched soil. The average difference determined for the three-year study period reached $10.6 \%$, but it was statistically non-significant. In 2007 and 2009, mulching had a significant effect on total yield. The average difference over three years of the study was $9.9 \%$ to the advantage of tomato plants grown in mulched plots. Previous research has shown that mulching enhances the yield potential of tomato plants as it increases soil temperature around the root system, supports weed control and suppresses the growth of soil pathogens (B u c z k o w s k a, 1995; K o ł o t a and W in i ar s ka, 2005; K a ro lew ski et al. 2008).

The interactions between habitat factors are an important consideration in plant production $(\mathrm{S}$ i w e $\mathrm{k}$ and Libik, 2005; Wierzbicka and Majk ow sk a- G a d o m sk a 2005), particularly in thermophilous vegetable growing (Kołota and Słociak, 2003; M i c hali k, 2007). In the present experiment, the cultivation method $\mathrm{x}$ cultivar interaction had a significant effect on early and marketable yield of tomato fruit. The highest early yield (mean of three years) was noted for 'Bawole Serce' grown in mulched soil, while the lowest one for cv. 'Złoty Ożarowski' grown in mulched plots. Tomato plants of cv. 'Bawole Serce' produced the highest average marketable yield when grown in control plots, and the lowest one when grown in mulched soil, but this trend was not validated statistically. Tomato plants 'Złoty Ożarowski' grown in mulched soil tended to produce a higher total yield. Similar relationships were observed by $\mathrm{W}$ i e r z b i c k a et al. (2003) for cucumbers grown in soil mulched with black PE sheet in the Warmia region.

Tomatoes are widely consumed around the globe due to their flavor and nutritional value. The flesh of ripe tomatoes contains valuable organic and mineral compounds whose concentrations vary depending on cultivar, growing conditions (Marty niak-Przybyszewska, 2000; Kołota and Winiarska, 2005; Majkowska-Gadomska et al. 2008), and the degree of ripeness ( $\mathrm{Zadernowski}$ and O s z m i ań s ki , 1994).

The main components of the edible parts of vegetables are water and dry matter. The processing suitability of plant materials is largely determined by dry matter content. In this experiment, dry matter concentrations in tomato fruit varied significantly depending on the cultivar and the cultivar $\mathrm{x}$ cultivation method interaction (Table 2). A comparison of the analyzed cultivars showed that tomato fruits of cv. Zloty Ożarowski harvested from control and mulched plots were characterized by a higher dry matter content than tomato fruits of cv. Bawole Serce. The dry matter content of the latter was lowest in the control treatment. The obtained results are consistent with the findings of Rożek (2001), Martyniak - Prz y bys zew ska (2000), Winiarska and Kołota (2007), and Majkowska-Gadomska et al. (2008). The biological value of the edible parts of vegetables is determined by L-ascorbic acid levels which, according to K u n a chowic z et al. (2006), should oscillate around $23 \mathrm{mg} \times 100 \mathrm{~g}^{-1}$. In the present study, the L-ascorbic acid content of tomato fruit ranged from $27.7 \mathrm{mg} 100 \mathrm{~g}^{-1}$ to $32.9 \mathrm{mg} \times 100 \mathrm{~g}^{-1}$, and it was not significantly affected by the experimental factors. The flavor and processing suitability of tomato fruit are also dependent on the concentrations of sugars and organic acids. Increased sugar levels improve the flavor of fruits and vegetables as well as the functional properties of tomatoes ( $\mathrm{Kulka}$ and Rejowski, 1998). The total sugar content of tomato fruit ranged from $3.4 \mathrm{~g} \times$ $100 \mathrm{~g}^{-1}$ to $4.6 \mathrm{~g} \times 100 \mathrm{~g}^{-1}$, and organic acid levels varied from $0.7 \mathrm{~g} \times 100 \mathrm{~g}^{-1}$ to $0.8 \mathrm{~g} \times 100 \mathrm{~g}^{-1}$ (Table 2). The noted differences were statistically non-significant. The total sugar to organic acid ratio in tomato fruit suitable for direct consumption ranged from 4.4 to 5.8, and it was close to the minimum value for good quality raw material intended for processing (6-10) (Z a d e r nowski and Oszmiański, 2004).

The suitability of fruits for processing or fresh consumption is also determined by the presence of nitrates, regarded as undesirable mineral compounds in fruits. The average nitrate levels in tomato fruit remained within permissible limits $\left(250 \mathrm{mg} \mathrm{NO}_{3}^{-} \times \mathrm{kg}^{-1}\right.$ fresh weight) (Journal of Laws No. 2, item 9, 2005). Cultivar had no significant effect on the nitrate content of tomato fruit, which was significantly affected by the cultivation method and the method $\mathrm{x}$ cultivar interaction. Tomato fruits of 'Złoty Ożarowski' harvested from plants grown in mulched soil had the lowest nitrate concentrations, whereas the highest nitrate levels were found in tomato fruits of this cultivar harvested from control plots. Previous research has shown that nitrate levels may be a genetic or varietal feature, but they can also be considerably modified by environmental conditions and agronomic factors ( $\mathrm{S}$ a u 11, 1990; R o że k, 2000; W o j c i e chow s k a et al. 2000).

The nutritional value of vegetables may be evaluated based on the ascorbate index. As demonstrated by P o k l u d a (2006), the value of the ascorbate index depends on plant species, cultivar and growing conditions. According to $\mathrm{Lachman}$ et al. (1997), the value of the ascorbate index $\left(\mathrm{I}_{\mathrm{AN}}\right)$ should be higher than 
1. In a study conducted by the cited author, the average values of $\mathrm{I}_{\mathrm{AN}}$ were as follows: pepper - 106, cabbage -1.54 , parsley -1.33 , celery -0.15 . In the present experiment, the values of $\mathrm{I}_{\mathrm{AN}}$ in tomato fruit ranged from 1.6 to 2.3. Tomato fruits of 'Złoty Ożarowski', particularly those harvested from control plots, had more desirable values of the ascorbate index. 'Bawole Serce' also responded positively to cultivation without mulching, since better light conditions supported vita$\min \mathrm{C}$ accumulation and a reduction in nitrate levels (Rożek, 2000; B i e s i a d a, 2008; G a j c-Wol$\mathrm{s} \mathrm{k}$ a et al. 2008).

Table 1

Total and marketable yield of field-grown tomatoes in 2007-2009

\begin{tabular}{|c|c|c|c|c|c|c|c|c|c|c|c|c|c|}
\hline \multirow{2}{*}{ Cultivar } & \multirow{2}{*}{$\begin{array}{l}\text { Cultivation } \\
\text { method }\end{array}$} & \multicolumn{4}{|c|}{$\begin{array}{l}\text { Early yield } \\
\left(\mathrm{t} \times \mathrm{ha}^{-1}\right)\end{array}$} & \multicolumn{4}{|c|}{$\begin{array}{l}\text { Marketable yield } \\
\qquad\left(\mathrm{t} \times \mathrm{ha}^{-1}\right)\end{array}$} & \multicolumn{4}{|c|}{$\begin{array}{l}\text { Total yield } \\
\left(\mathrm{t} \times \mathrm{ha}^{-1}\right)\end{array}$} \\
\hline & & 2007 & 2008 & 2009 & Mean & 2007 & 2008 & 2009 & Mean & 2007 & 2008 & 2009 & Mean \\
\hline \multirow{3}{*}{ Bawole Serce } & Control & 5.1 & 20.4 & 5.9 & 10.4 & 7.1 & 53.0 & 26.7 & 28.9 & 17.6 & 64.9 & 35.5 & 39.3 \\
\hline & Mulch & 18.4 & 35.0 & 5.0 & 19.4 & 4.7 & 42.0 & 24.7 & 23.8 & 38.8 & 58.1 & 33.1 & 43.3 \\
\hline & Mean & 11.7 & 27.7 & 5.4 & 14.9 & 5.9 & 47.5 & 25.7 & 26.3 & 8.2 & 61.5 & 34.3 & 41.3 \\
\hline \multirow{3}{*}{ Złoty Ożarowski } & Control & 3.8 & 13.8 & 14.2 & 10.6 & 11.0 & 50.0 & 16.5 & 25.8 & 22.9 & 68.5 & 38.6 & 43.3 \\
\hline & Mulch & 15.1 & 11.6 & 2.5 & 9.7 & 21.3 & 36.2 & 17.5 & 25.0 & 63.1 & 47.8 & 31.9 & 47.6 \\
\hline & Mean & 9.4 & 12.7 & 8.3 & 10.1 & 16.1 & 43.1 & 17.0 & 25.4 & 43.0 & 58.1 & 35.2 & 45.4 \\
\hline \multirow{2}{*}{$\begin{array}{l}\text { Average for culti- } \\
\text { vation method }\end{array}$} & Control & 4.4 & 17.1 & 10.0 & 10.5 & 9.0 & 51.5 & 21.6 & 27.3 & 20.2 & 66.7 & 37.0 & 41.3 \\
\hline & Mulch & 16.7 & 23.3 & 3.7 & 14.5 & 13.0 & 39.1 & 21.1 & 24.4 & 51.0 & 52.9 & 32.5 & 45.4 \\
\hline \multicolumn{14}{|l|}{$\mathrm{LSD}_{0.05}$} \\
\hline \multicolumn{2}{|l|}{ Cultivar } & n.s. & 7.4 & n.s. & 4.7 & 4.6 & n.s. & 5.6 & n.s. & n.s. & 4.9 & n.s. & n.s. \\
\hline \multicolumn{2}{|c|}{ Average for cultivation method } & 1.9 & n.s. & 4.5 & n.s. & n.s. & 6.61 & n.s. & n.s. & 13.7 & n.s. & 3.5 & n.s. \\
\hline \multicolumn{2}{|l|}{ Interaction } & 1.3 & 1.6 & 1.9 & 1.9 & 1.3 & n.s. & 1.9 & 1.3 & 9.5 & 1.8 & n.s. & n.s. \\
\hline
\end{tabular}

Table 2

Concentrations of organic compounds and nitrates in fruits of field-grown tomatoes.

\begin{tabular}{|c|c|c|c|c|c|c|c|c|}
\hline \multirow{2}{*}{ Cultivar } & \multirow{2}{*}{$\begin{array}{l}\text { Cultivation } \\
\text { method }\end{array}$} & $\begin{array}{l}\text { Dry } \\
\text { matter }\end{array}$ & $\begin{array}{l}\text { L-ascorbic } \\
\text { acid }\end{array}$ & $\begin{array}{l}\text { Total sac- } \\
\text { charides }\end{array}$ & $\begin{array}{l}\text { Organic } \\
\text { acid }\end{array}$ & $\begin{array}{l}\text { Saccharides/ } \\
\text { organic acid }\end{array}$ & Nitrate (V) & $\begin{array}{l}\text { Ascorbate- } \\
\text { nitrate index }\end{array}$ \\
\hline & & $\%$ & $m g \times 100 g^{-1}$ & $\mathrm{~g} \times 100 \mathrm{~g}^{-1}$ & $g \times 100 g^{-1}$ & - & $\mathrm{mg} \times \mathrm{kg}^{-1} \mathrm{f} . \mathrm{w}$ & - \\
\hline \multirow{3}{*}{ Bawole Serce } & Control & 4.9 & 31.0 & 3.4 & 0.8 & 4.4 & 186.7 & 2.0 \\
\hline & Mulch & 5.3 & 29.2 & 3.5 & 0.7 & 4.9 & 185.6 & 1.6 \\
\hline & Mean & 5.1 & 30.1 & 3.4 & 0.8 & 4.6 & 186.1 & 1.8 \\
\hline \multirow{3}{*}{ Złoty Ożarowski } & Control & 5.4 & 32.9 & 3.5 & 0.7 & 4.7 & 202.5 & 2.3 \\
\hline & Mulch & 5.5 & 27.7 & 4.6 & 0.8 & 5.8 & 178.1 & 1.6 \\
\hline & Mean & 5.5 & 30.3 & 4.1 & 0.8 & 5.2 & 190.3 & 2.0 \\
\hline \multirow{2}{*}{$\begin{array}{l}\text { Average for culti- } \\
\text { vation method }\end{array}$} & Control & 5.3 & 31,0 & 3.5 & 0.8 & 4.5 & 194.6 & 2.2 \\
\hline & Mulch & 5.4 & 29.2 & 3.8 & 0.8 & 5.3 & 181.8 & 1.6 \\
\hline $\mathrm{LSD}_{0.05}$ & & 0.2 & n.s. & n.s. & n.s. & & n.s. & \\
\hline Cultivar & & 0.2 & n.s. & n.s. & n.s. & - & 8.7 & - \\
\hline $\begin{array}{l}\text { Cultivation method } \\
\text { Interaction }\end{array}$ & & 0.2 & n.s. & n.s. & n.s. & & 1.1 & \\
\hline
\end{tabular}




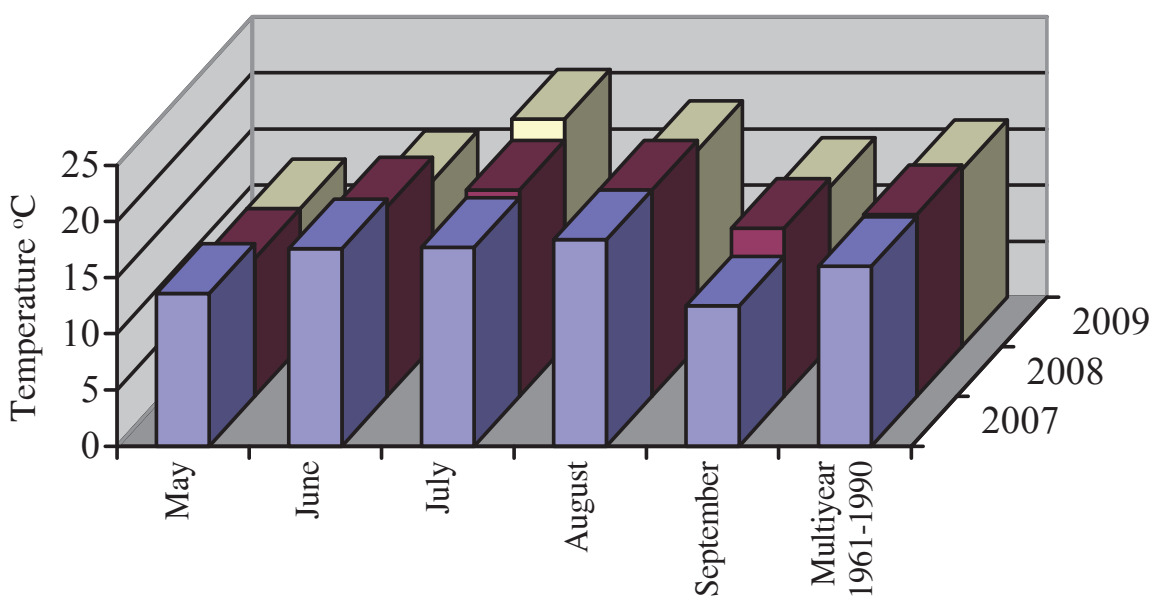

Fig. 1. Mean temperatures over the experimental period - data provided by the Meteorological Station in Olsztyn.

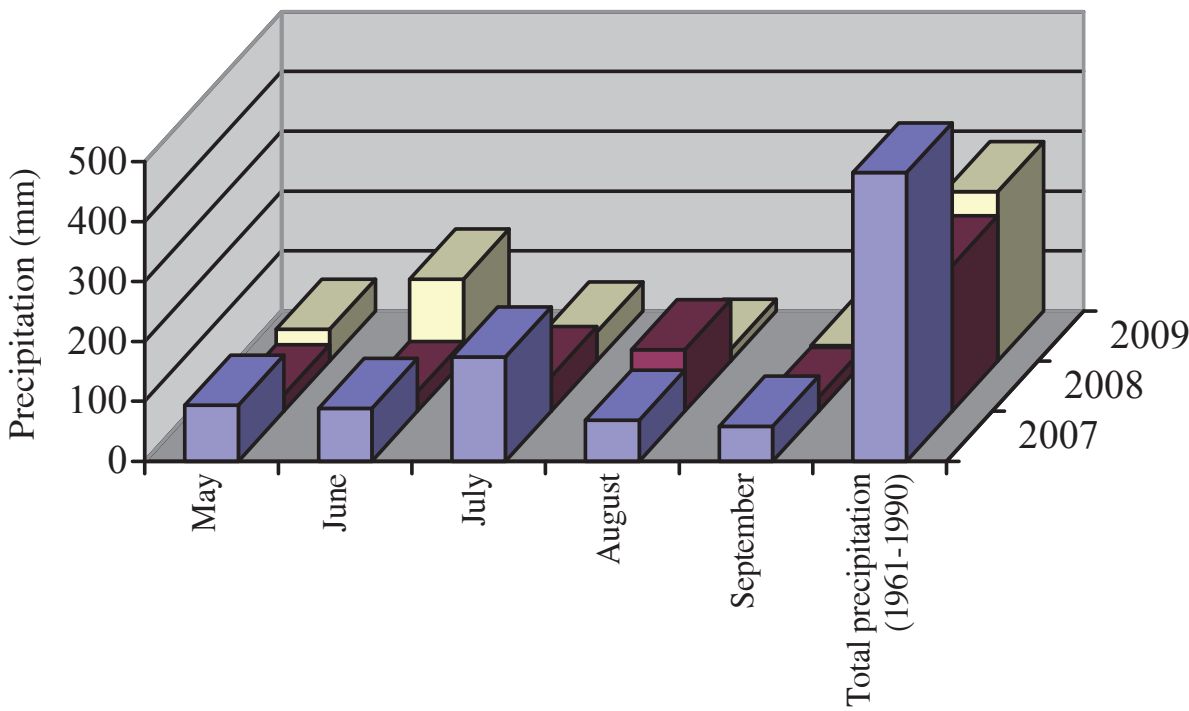

Fig. 2. Precipitation totals over the experimental period - data provided by the Meteorological Station in Olsztyn.

\section{CONCLUSIONS}

1. Soil mulching with black non-woven PP 50 fabric contributed to an increase in early yield of field-grown tomatoes 'Bawole Serce', compared with the control treatment.

2. Fruits harvested from tomato plants 'Złoty Ożarowski' had a higher dry matter content.

3. Soil mulching had no significant effect on the concentrations of the analyzed organic compounds in tomato fruit.

4. Nitrate levels in tomato fruit remained within permissible limits, and they were significantly affected by the cultivation method and the method $\mathrm{x}$ cultivar interaction.

\section{Acknowledgements}

Edition of publication subsided within project 1014.0804.

\section{REFERENCES}

Adamczewska-Sowińska K., Kołota E. 2007. Żywe ściółki w uprawie pomidora. / Living mulches in tomato production. Rocz. Akad. Rol. W Poznaniu CCCLXXXIII: 411-415. (in Polish)

Akintoye H.A., Agbeyi E.O., Olaniyan A.B. 2005. The effects of live mulches on tomato (Lycopersicon esculentum) yield under tropical conditions. J. Agric. 26(1): 2737. http://dx.doi.org/10.1300\%2FJ064v26n01_04

Babik I. 1997. Pomidory gruntowe. PWRiL, Warszawa. (in Polish)

Buczkowska H. 1999. Wpływ ściółkowania gleby na zachwaszczenie w uprawie papryki słodkiej. / The effect of soil mulching on weed infestation in red pepper cultivation. Zesz. Probl. Post. Nauk Rol. 466: 157-163. (in Polish)

Grabowska K., Banaszkiewicz B., Szwejkowski Z . 2004. Niedobory i nadmiary opadów na terenie województwa Warmińsko-Mazurskiego w latach 
2000-2002. / Deficiencies and excess of precipitation within the Warmia and Mazury Province in 2000-2002. Acta Agrophys. 3 (1): 57-64. (in Polish)

Grabowski J., Olba-Zięty E., Grabowska K. 2007. Zróżnicowanie warunków meteorologicznych w dwóch mezoregionach i ich wpływ na plon ziemniaka. / Differentiation in meteorological conditions and their influence on potato yield in two mesoregions. Acta Agrophys. 9 (2): 353-359. (in Polish)

Karolewski Z., Grzegorzewski A., Werner M. 2008. Choroby bakteryjne i grzybowe występujące na różnych odmianach pomidora uprawianych w gruncie. / Bacterial and fungal diseases occurring on different tomato cultivars in field cultivation. Prog. Plant Protect./ Pos. Ochr. Roślin 48(1): 190-193. (in Polish)

Kołota E., Winiarska S. 2005. Porównanie plonowania kilku odmian pomidora (Lycopersicon esculentum Mill.) w uprawie przy palikach. / Comparison of yielding of some staked tomato cultivars (Lycopersicin esculentum Mill.) grown in the open field. Zesz. Nauk. Akad. Rol. We Wrocławiu. 515. LXXXVI: 251-159. (in Polish)

Koźmiński Cz., Michalska B. 2001. Atlas Klimatycznego Ryzyka Uprawy Roślin w Polsce. Wyd. Akad. Rol. Szczec. (in Polish).

Kulka K., Rejowski A. 1998. Biochemia. Wyd. ART, Olsztyn. (in Polish)

Kunachowicz H., Nadolna I., Przygoda B., Iw a now K. 2006. Tabele wartości odżywczej produktów spożywczych. Prace Instytutu Żywności i Żywienia, Warszawa. (in Polish)

Krauze A., Domska D. 1991. Ćwiczenia specjalistyczne z chemii rolnej. Wyd. ART, Olsztyn. (in Polish)

Martyniak-Przybyszewska B. 2000. Ocena plonowania i jakości pomidora w uprawie pod osłonami. / Evaluation of yield and quality of tomato in protected cultivation. Zesz. Nauk. Akad. Rol. w Krakowie 364 (71): 135-138. (in Polish).

Michalik Ł. 2007. Wzrost i plonowanie papryki słodkiej (Capsicum annuum L.) uprawianej w polu w warunkach klimatycznych Olsztyna. / Growth and yielding of sweet pepper (Capsicum annuum L.) grown in field in the climatic conditions of Olsztyn. Rocz. Akad. Rol. Pozn. Ogrod. CCCLXXXIII (41): 571-575. (in Polish)

Oznaczanie zawartości suchej masy metodą wagową. PN-90/A-75101/ 03. (in Polish)

Oznaczanie zawartości cukrów i ekstraktu bezcukrowego. PN-90/A-75101/07. (in Polish)

Oznaczanie zawartości witaminy C. PN-90/A -75101/11. (in Polish)

Rocznik Statystyczny Rolnictwa. 2009. Główny Urząd Statystyczny, Warszawa. (in Polish)

Rozporządzenie Ministra Zdrowia z dnia 22 grudnia 2004 r. Dziennik Ustaw nr 2, poz. 9. 2005. W sprawie mak- symalnych poziomów zanieczyszczeń chemicznych i biologicznych, które mogą znajdować się w żywności, składnikach żywności, dozwolonych substancjach dodatkowych, substancjach pomagających w przetwarzaniu albo na powierzchni żywności. (in Polish)

Rożek S. 2000. Czynniki wpływające na akumulację azotanów w plonie warzyw. / Factors affecting nitrate accumulation in vegetable yield. Zesz. Nauk. Akad. Rol. w Krakowie, 364 (71):13-18. (in Polish)

Rożek E. 2001. Ocena jakości owoców kilku odmian pomidora do przetwórstwa. Ogólnopol. Konf. Nauk. Biologiczne i agrotechniczne kierunki rozwoju warzywnictwa. Skierniewice, 21-22 czerwca 2001 r.: 128-129. (in Polish)

Siwek P., Kalisz A., Wojciechowska R. 2007. Effect of mulching with film of different colours made from original and recycled polyethylene on the field of butterhead lettuce and celery. Folia Hort. Supl. 19,1: 25-35.

Siwek P., Libik A. 2005. Wpływ osłon z folii i włókniny w uprawie wczesnego selera naciowego na wielkość i jakość plonu. / The effect of plastic sheet and geotextile covers in the cultivation of early stalk celery on the amount and quality of yield. Zesz. Nauk. Akad. Rol. Wroc. Rol. 515, 86: 483-490. (in Polish)

Siwek P., Libik A., Twardowska-Schmidt K., Ciechańska D., Gryza I. 2010. Zastosowanie biopolimerów w rolnictwie. / Biopolymers and their applications in agriculture. Polimery. 55 (11-12):801811. (in Polish)

St a ck J.R. 1997. Uprawa roli i nawożenie roślin ogrodniczych. PWRiL, Warszawa. (in Polish)

Winiarska S., Kołota E. 2007. Porównanie plonowania i wartości odżywczej wybranych odmian pomidora $\mathrm{w}$ uprawie przy palikach w tunelu foliowym. / Comparison of yielding and nutritional value of chosen staked tomato cultivars grown under plastic tunnel. Rocz. Akad. Rol. Pozn. CCLXXXIII(41), 655-659. (in Polish)

Wierzbicka B., Majkowska-Gadomska J. 2005. Plonowanie i zawartość wybranych składników chemicznych w owocach ogórka partenokarpicznego w uprawie przyspieszonej. / Yield and content of some chemical in the fruit of parthenocarpic cucumber in accelerated cultivation. Zesz. Probl. Post. Nauk Roln. 507: 569-574. (in Polish)

Wojciechowska R., Smoleń S., Przybyło J. 2000. Zawartość azotanów w różnych częściach użytkowych wybranych gatunków warzyw. / Nitrate content in different useful parts of vegetable species. Zesz. Nauk. Akad. Rol. Kraków, 364 (71): 205-208. (in Polish)

Zadernowski R., Oszmiański J. 1994. Wybrane zagadnienia z przetwórstwa owoców i warzyw. Wyd ART, Olsztyn. (in Polish) 


\section{Plonowanie i wartość odżywcza owoców pomidora polowego \\ (Lycopersicon esculentum Mill.) $\mathrm{z}$ uprawy roślin na glebie ściółkowanej}

\section{Streszczenie}

Badania nad plonowaniem pomidora uprawianego w polu przeprowadzono w latach 2007-2009 w Ogrodzie Zakładu Dydaktyczno-Doświadczalnego Uniwersytetu Warmińsko-Mazurskiego w Olsztynie. Materiał do badań stanowiły dwie odmiany pomidora: Bawole Serce i Złoty Ożarowski. Rośliny uprawiano bezpośrednio w polu oraz na glebie ściółkowanej czarną włókniną PP 50. Wybór odmiany miał istotny wpływ tylko na średni plon wczesny w uprawie odmiany Bawole Serce. Największy plon wczesny, średnio z trzech lat badań, uzyskano z roślin odmiany Bawole Serce uprawianych na glebie ściółkowanej, natomiast istotnie najmniej owoców zebrano z uprawy roślin odmiany Złoty Ożarowski również w obiekcie ze ściółkowaniem. Plon handlowy owoców pomidora był istotnie większy w obu obiektach, w których uprawiano rośliny odmiany Bawole Serce. Większą zawartością suchej masy charakteryzowały się owoce pochodzące $\mathrm{z}$ roślin odmiany Złoty Ożarowski. Ściółkowanie gleby w uprawie tej odmiany istotnie zwiększyło poziom zawartości suchej masy w owocach. Zawartość kwasu L-askorbinowego, cukrów ogółem i kwasów organicznych nie była uzależniona od badanych czynników. Poziom zawartości azotanów (V) w częściach jadalnych analizowanych odmian pomidora nie przekraczał dopuszczalnej dla organizmu ludzkiego normy i istotnie zależał od sposobu uprawy roślin i jego współdziałania z odmianą. Ograniczeniu gromadzenia azotanów (V) sprzyjała uprawa roślin pomidora odmiany Ożarowski Złoty na glebie ściółkowanej. 
